\title{
Taxonomy and molecular phylogeny of Myxobolus bilobus n. sp. (Myxozoa) parasitizing Notemigonus crysoleucas (Cyprinidae) in Algonquin Park, Ontario, Canada
}

\author{
David K. Cone ${ }^{1, *}$, Jing Yang ${ }^{1}$, Genlou Sun ${ }^{1}$, Russell Easy ${ }^{2}$ \\ ${ }^{1}$ Department of Biology, Saint Mary's University, Robie Street, Halifax, Nova Scotia B3H 3C3, Canada \\ ${ }^{2}$ National Research Council, Institute for Marine Biosciences, Oxford Street, Halifax, Nova Scotia B3H 3Z1, Canada
}

\begin{abstract}
Myxobolus bilobus n. sp. (Myxozoa) is described from golden shiner Notemigonus crysoleucas in Algonquin Park, Ontario, Canada. Plasmodia develop at the distal end of gill filaments, where they form a novel-shaped plasmodium made up of 2 side-by-side hemispheres joined at a central pore. Surrounding gill tissue is vacuolated, necrotic, and hemorrhagic. Spores of M. bilobus n. sp. resemble those of $M$. aureatus Ward, 1919, M. angustus Kudo, 1934, M. spalli Landsberg \& Lom, 1991, and M. pseudokoi Li \& Desser, 1985 in parasitizing cyprinids and in their pyriform shape. Spores of $M$. bilobus n. sp., however, are much larger (20 to $22.1 \mu \mathrm{m}$ long, 7.5 to $9.3 \mu \mathrm{m}$ wide, and $6 \mu \mathrm{m}$ thick) than those of these other species, and the plasmodium is bi-lobed rather than the typical hollow sphere. A phylogenetic analysis of the 18S rDNA (2014 bp) reveals that M. bilobus $\mathrm{n}$. sp. is a member of a clade that includes 11 species of Myxobolus, all of which are parasites of cyprinid fishes in North America or Eurasia. The study concludes that $M$. bilobus $\mathrm{n}$. sp. is a member of a clade that has undergone radiation within cyprinid fishes of the 2 continents and that this evolution has involved both host and site switching.
\end{abstract}

KEY WORDS: Myxozoan · Myxobolus bilobus n. sp. · Notemigonus crysoleucas Resale or republication not permitted without written consent of the publisher

\section{INTRODUCTION}

During a study of myxozoan parasites of fishes in Algonquin Park, Ontario, Canada, a species of Myxobolus Bütschli, 1882 (Myxozoa) that formed an unusual bi-lobed plasmodium in gill filaments of golden shiner Notemigonus crysoleucas was found. The present study describes the parasite as Myxobolus bilobus $\mathrm{n}$. sp., reports on the structure of the plasmodium as seen with light microscopy, and determines the phylogenetic relationship of this new species relative to previously studied species in which the $18 \mathrm{~S}$ rDNA is known.

\section{MATERIALS AND METHODS}

Fish and necropsy. A total of 32 adult golden shiner Notemigonus crysoleucas from Brewer Lake and Lake Opeongo, Algonquin Park, were collected on 17 to 19 May 2004 by seine net. Fish were killed by cervical incision and necropsied immediately. 'Cysts' (plasmodium and surrounding host tissue) were examined in wet mounts under slight coverslip pressure. About 20 cysts were fixed either in $10 \%$ buffered formalin or in absolute ethanol. Formalin-fixed samples were prepared histologically using standard techniques and stained with hematoxylin and eosin, Giemsa, Masson's 
trichrome, or Verhoeff's elastin stain (Presnell \& Schreibman 1997). Fresh spores were stained with Lugol's iodine (iodinophilous vacuole) and with $1 \%$ methylene blue (mucous coat). Fixed sporoblasts and developed spores were prepared in $1 \%$ agar mounts and photographed.

DNA sequencing. Ethanol-fixed specimens were air-dried and incubated in $200 \mu \mathrm{l}$ TE buffer $(10 \mathrm{mM}$ Tris$\mathrm{HCl}, \mathrm{pH} 7.6,1 \mathrm{mM}$ EDTA) with Proteinase K (200 $\mu \mathrm{g}$ $\mathrm{ml}^{-1}$ ) and $\mathrm{SDS}(1 \%)$ at $55^{\circ} \mathrm{C}$ for $30 \mathrm{~min}$. After classical extraction using phenol/chloroform, DNA was precipitated from the aqueous phase with 0.1 vol of $3 \mathrm{M}$ sodium acetate (pH 5.2) and 2 vol of $100 \%$ ethanol and collected by centrifugation. The pellet was washed with $70 \%$ ethanol, air dried, and re-suspended in $60 \mu \mathrm{TE}$ buffer. The 18S rDNA was amplified using primers 18r (5' -CTACGGAAACCTTGTTACG-3') (Whipps et al. 2003) and 18e (5'-CTGGTTGATCCTGCCAGT-3') (Hillis \& Dixon 1991). Approximately 200 ng of the DNA was used as a template in a $50 \mu \mathrm{l}$ PCR reaction, including $0.4 \mu \mathrm{M}$ of each primer, $0.2 \mathrm{mM}$ dNTPs, $1.5 \mathrm{mM} \mathrm{MgCl}_{2}, 1 \times \mathrm{PCR}$ buffer, and 2 U Taq polymerase (Fermentas). Cycling was performed under the following conditions: $3 \mathrm{~min}$ at $94^{\circ} \mathrm{C}, 35$ cycles of $30 \mathrm{~s}$ at $94^{\circ} \mathrm{C}, 30 \mathrm{~s}$ at $50^{\circ} \mathrm{C}$, and $2 \mathrm{~min}$ at $72^{\circ} \mathrm{C}$, followed by final extension at $72^{\circ} \mathrm{C}$ for $10 \mathrm{~min}$. A 2014 bp PCR product was excised from an agarose gel and purified using QIAquick Gel Extraction Kit (Qiagen). The purified fragment was cloned into a pDrive cloning-vector (Qiagen). Plasmid DNA from a single clone was sequenced using M13 forward (5'-GT AAAACGACGGCCAG-3') and M13 reverse (5'CAGGAAACAGCTATGAC-3') primers. Primer 18 m (5'-CGCGGTAA TTCCAGCT CCA-3') was designed to enable sequencing of the middle part of the $18 \mathrm{~S}$ rDNA. DNA sequencing software (http://arep.med.harvard.edu/labgc/adnan/ projects/Utilities/revcomp.html) was used to convert the sequence into complimentary strands. The sequences were aligned with BLASTN (http://www.ncbi.nlm.nih.gov/ blast/bl2seq/ wblast2.cgi), overlapping sequences were removed, and sequences joined to obtain the full length 18S rDNA.

Molecular phylogeny. Sequences were compared using Clustal X software (Thompson et al. 1997). Phylogenetic analyses were conducted using PAUP Version 4.0b10 (Swofford 2001) and included parsimony, maximum-likelihood, and neighbor-joining distance methods. The phylogeny was calculated using neighborjoining methods and bootstrap analysis with 1000 replicates with Ceratomyxa shasta Noble, 1950 (AF001579) as the outgroup. All morphological measurements are presented in micrometers unless stated otherwise.

\section{RESULTS}

\section{Myxobolus bilobus n. sp.}

Description: Plasmodium typically bi-lobed, up to $1 \mathrm{~mm}$ in diameter (Fig. 1). Disporoblastic, with asynchronous spore development (see Fig. 3). Spores (Figs. 2 to 5) pyriform in frontal view, relatively large, $21 \pm 0.6$ (20 to 22.1) $(\mathrm{N}=13)$ long, $8.4 \pm 0.5$ (7.5 to 9.3) wide, 6 thick; length-to-width ratio $1: 2.49( \pm 0.16)$ (1:2.31 to $1: 2.81$ ). Polar capsules pyriform, with distinct neck region, dissimilar in size (paired $t$-test, $t=-4.26$, $\mathrm{p}=0.001, \mathrm{~N}=13)$; large capsule $10.8 \pm 0.7$ (9.2 to 12$)(\mathrm{N}$ =13) long, $2.7 \pm 0.2$ (2.2 to 3.6) wide; small capsule 10.1 \pm 0.7 (9.1 to 11$)(\mathrm{N}=13)$ long, $2.8 \pm 0.2$ (2.4 to 3.2) wide. Polar capsules converging anteriorly, but not crossing and not reaching spore apex; 7 to 9 tight polar filament coils, arranged perpendicular to capsule length. Intercapsular appendix, iodinophilous vacuole and mucous coat absent.

Type host: Golden shiner Notemigonus crysoleucas (Cyprinidae).
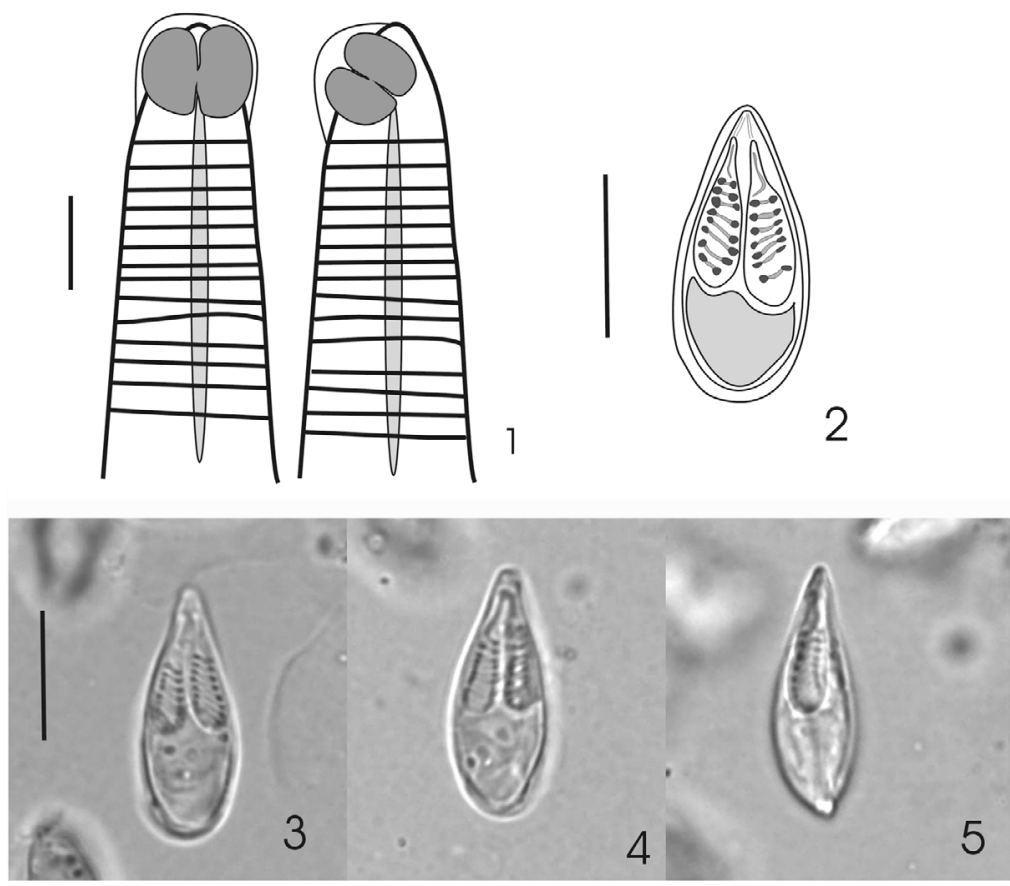

Figs. 1 to 5. Plasmodia and spores of Myxoblus bilobus n. sp. from Notemigonus crysoleucas in Algonquin Park, Ontario, Canada. Fig. 1. Line drawing of bi-lobed plasmodia at the distal tip of gill filaments. Scale bar $=$ $1 \mathrm{~mm}$. Fig. 2. Line drawing of a typical spore. Scale bar $=10 \mu \mathrm{m}$. Figs. $3 \& 4$. Photomicrographs of developed spores in frontal view. Scale bar $=10 \mu \mathrm{m}$. Fig. 5. Developed spore in lateral view. Scale for Figs. $4 \& 5$ as for Fig. 3 
Type locality: Brewer Lake, Algonquin Park, Ontario $\left(45^{\circ} 35^{\prime} \mathrm{N}, 78^{\circ} 19^{\prime} \mathrm{W}\right)$.

Other localities: Lake Opeongo, Algonquin Park, Ontario.

Site of tissue development: Distal gill filaments.

Type material: A Giemsa-stained histological section of a plasmodium containing developed spores has been deposited as a syntype slide to the United States National Parasite Collection (USNPC) (Accession Number 96438), Beltsville, Maryland, USA. Etymology: The species is named after its bi-lobed plasmodium.

Prevalence of infection: $63.3 \%$ (19 of 30).

Intensity of infection: 1 to 5 'cysts'.

Histology of infection: Plasmodia were bilobed in cross-section, consisting of 2 hemispheres joined by a central pore. They were fluid filled and contained loosely arranged, peripheral sporoblasts and debris. The outer margin was a fibrous, eosinophilic layer, measuring 3 to $10 \mu \mathrm{m}$ thick (Fig. 6), that stained deep red with Masson's trichrome and deep blue with Verhoeff's elastin stain (the latter 2 colors being negative for elastin). Its outer surface was smooth, the inner surface irregular. Hyperplastic epithelium and connective tissue that surrounded the plasmodia were typically vacuolated, necrotic, and hemorrhagic (Fig. 6). In freshly killed hosts the 'cysts' were fragile and, if touched with fine tweezers, readily burst and released a cloud of spores.

Comments: Myxobolus bilobus n. sp. resembles M. aureatus Ward, 1919, M. angustus Kudo, 1934, M. spalli Landsberg \& Lom, 1991, and M. pseudokoi Li \& Desser, 1985 in that they develop within cyprinid hosts in North America and they have similar pyriform-shaped spores (Table 1). Spores described herein are longer than those of the other species (20 to $22.1 \mu \mathrm{m}$ vs. $\leq 16.6 \mu \mathrm{m})$, giving the spore a narrow pyriform appearance. In addition, the polar capsules are dissimilar in length, with the larger one being generally longer (9.1 to $12 \mu \mathrm{m}$ vs. $\leq 9.5 \mu \mathrm{m}$ ) than those of the other species (Table 1). The bi-lobed plasmodium of $M$. bilobus n. sp. is also novel among these and other species within the genus. A typical spore of $M$. bilobus n. sp. (see Fig. 11) is compared to those of $M$. angustus, $M$. aureatus, and M. pseudokoi at identical magnifications to illustrate the morphological differences (Figs. 7 to 10$)$.

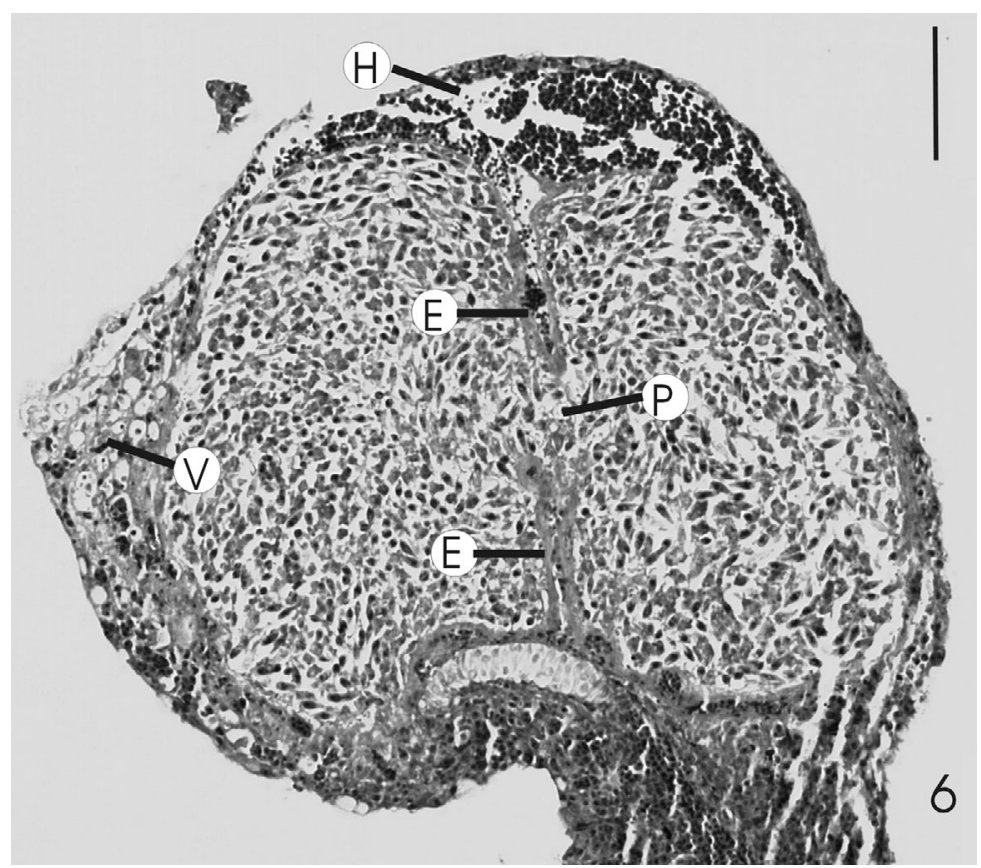

Fig. 6. Myxobolus bilobus n. sp. Histological section through a 'cyst' showing the central pore $(\mathrm{P})$, the presumed ectoplasm $(\mathrm{E})$, vacuolated and necrotic epidermis $(\mathrm{V})$, and a hemorrhagic $(\mathrm{H})$ area. Scale bar $=100 \mu \mathrm{m}$. Hematoxylin and eosin stain

Molecular phylogeny: Sequence data for a $2014 \mathrm{bp}$ region of the 18S rDNA (GenBank DQ008579) was successfully determined. The topology of the phylogenetic trees produced using parsimony, maximumlikelihood and neighbor-joining methods were the same. Myxobolus bilobus n. sp. occurred, with high bootstrap support, within a clade (Fig. 11) that included 10 other species of Myxobolus from gill or muscle tissue of various cyprinid fishes from North America or Eurasia.
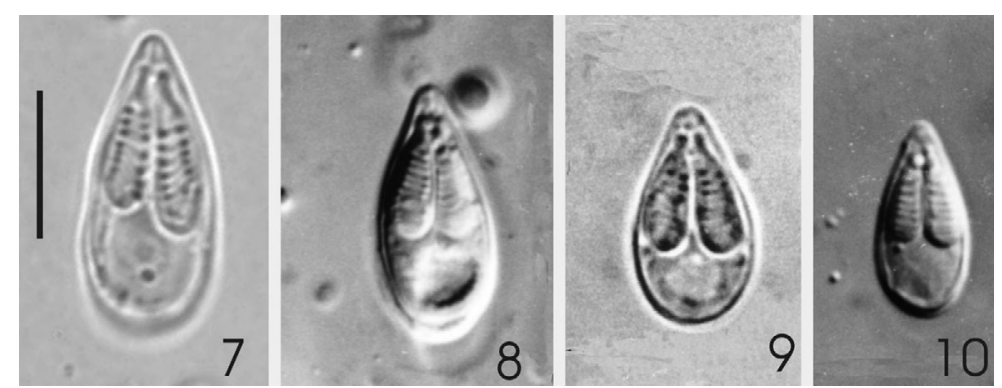

Figs. 7 to 10. Myxobolus spp. A comparison of formalin-fixed spores. Fig. 7 . M. bilobus n. sp. collected in the present study (scale bar $=10 \mu \mathrm{m}) \overline{\text { Fig. } 8 .}$ M. angustus Kudo, 1934 collected from the gills of Pimephales promelas in August 1993, Duluth, Minnesota. Fig. 9. M. aureatus from the fins of Pimephales promelas, September 1986, as reproduced from Lom et al. (1992, their Fig. 2). Fig. 10. M. pseudokoi Li \& Desser, 1985 collected from the gills of Luxilus cornutus in June 1994, Lake Opeongo, Algonquin Park. All spores at similar magnifications 


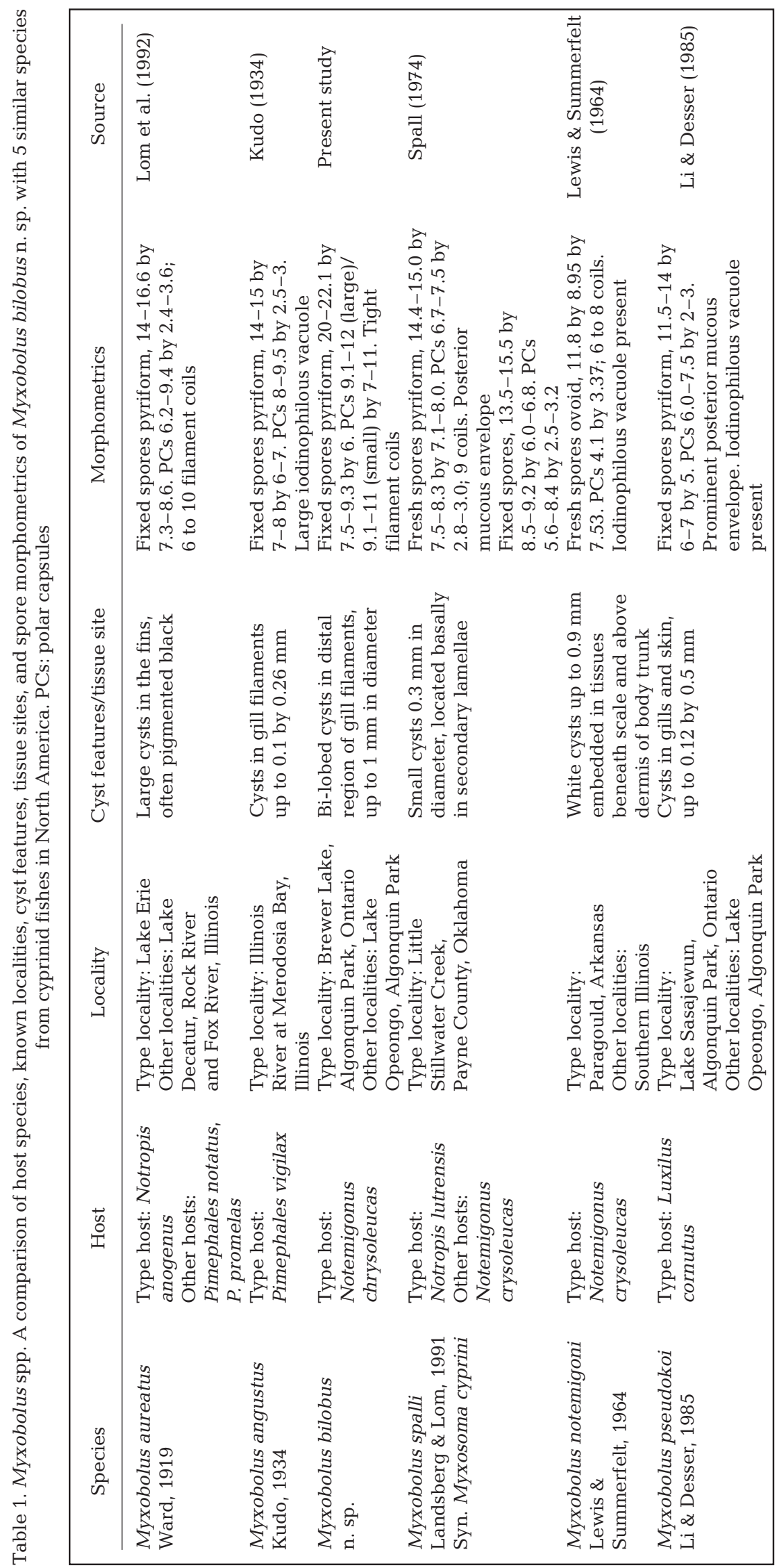

\section{DISCUSSION}

Molnár (2002) summarized the microhabitats within the gill filaments, lamellae, and arches of fishes that are utilized by myxozoans, emphasizing the need to include the exact site of development in species descriptions so as to go beyond 'gills'. In the present study we report that Myxobolus bilobus $\mathrm{n}$. sp. develops consistently in tissues near the distal tip of the filament. The exact site of development was not determined because initial developmental stages were absent from the fish examined. The lack of positive staining for elastin, a main structural component of fish arteries (Roberts 1989), at the margin of the cyst suggests that development does not take place within the afferent artery, a common site of development of myxobolids within the distal tissues of the gill filament (Molnár 2002).

Host tissue surrounding the developed plasmodium of Myxobolus bilobus n. sp. undergoes degeneration and necrosis, leading to the hemorrhagic cyst that is sensitive to rupturing as observed during necropsy. Spontaneous rupturing of gill-dwelling plasmodia is known to occur (Dyková \& Lom 1978, Cone 1994, Molnár 1998). The process has been linked to an intense inflammatory reaction (Dyková \& Lom 1978) that ultimately leads to dispersal of myxospores to the outside environment (Cone 1994). In the case of $M$. bilobus n. sp. there is an extensive build-up of hyperplastic tissues, and we suspect that significant necrosis of this tissue is necessary before spores can be effectively released.

Gill-dwelling myxobolids typically produce a spherical to oval plasmodium comprised of a relatively thin, peripheral ectoplasm containing a germinal layer of sporoblasts and a fluid-filled inner endoplasm containing a mass of irregularly arranged spores and debris. The plasmodium can be taxonomically important in situations in which they occur at a specific site within gill tissue (Molnár 2002), when the fully developed plasmodium is noticeably small or 


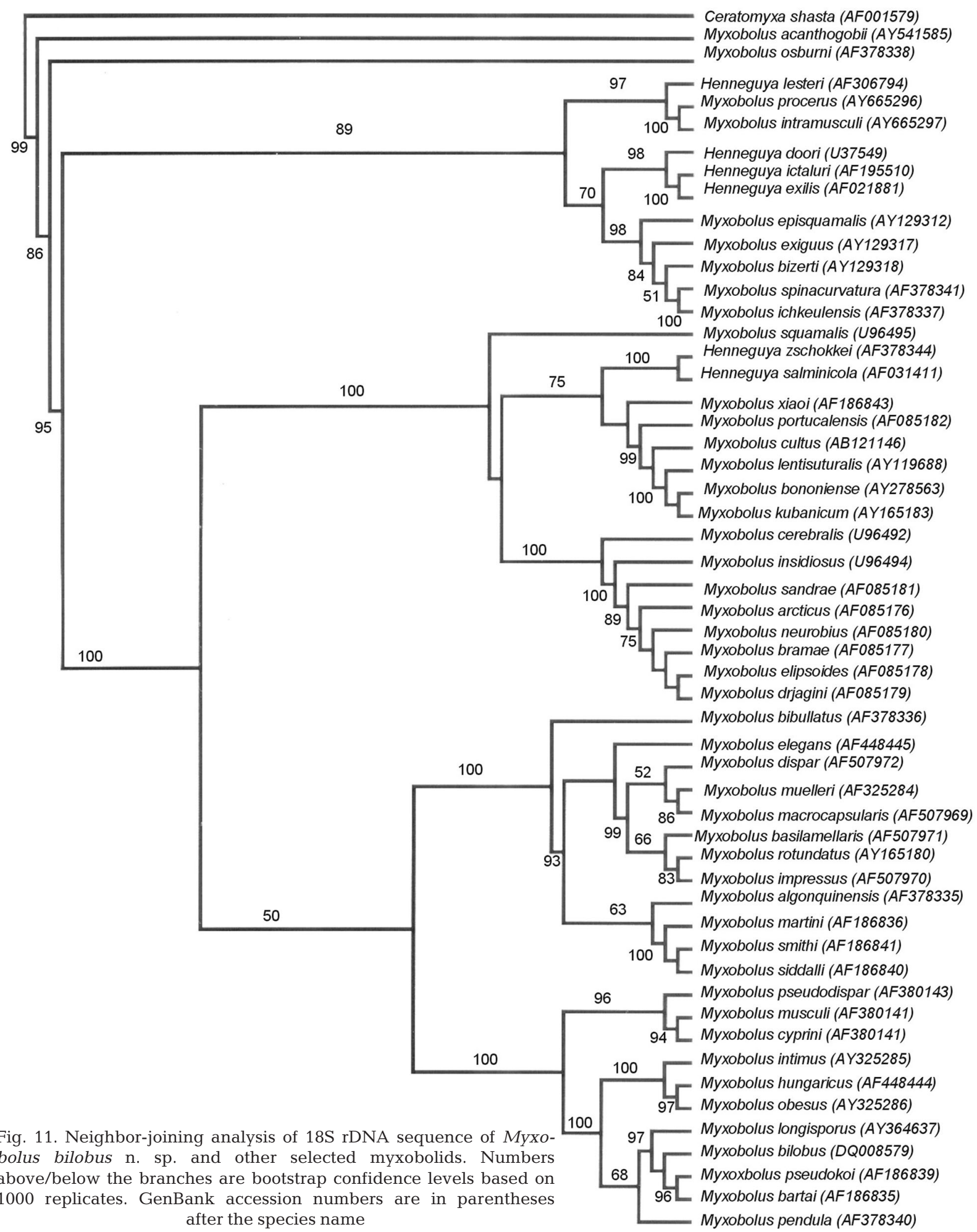

large (Price \& Mellen 1980), when the relative thickness and cellular makeup of the ectoplasm is novel (Mavor 1916, Martyn et al. 2002), and/or when the plasmodium is freeform, engulfing, but not destroying, the capillary bed (Cone \& Wiles 1985). The bi-lobed plasmodium of Myxobolus bilobus sp. appears to be another example of such diagnostic use of the plasmodium. The preliminary histochemistry suggests that the prominent eosinophilic layer at the outer edge of the plasmodium is entirely ectoplasm, devoid of any 
incorporation of host cells. The facts that the apparent ectoplasm is continuous throughout the periphery and that the endoplasm of the 2 spheres are connected via the central pore suggest that the bi-lobed form arises from a single plasmodium and not from fusion of 2 smaller ones.

Easy et al. (2005) reviewed the application of $18 \mathrm{~S}$ rDNA to the taxonomy of species of Myxobolus and other myxozoans and concluded that intraspecific variation in sequence alignment was typically $<1 \%$. The present study supports this conclusion because $M$. bilobus has only $\leq 96 \%$ similarity in alignment of the $18 \mathrm{~S}$ rDNA with other studied species in the genus.

The phylogenetic analysis reveals that Myxobolus bilobus $\mathrm{n}$. sp. is a member of a clade that has undergone a major radiation within cyprinid fishes in North America and Eurasia. Members include M. pseudodispar, M. musculi, M. cyprini, $M$. intimus, $M$. hungaricus, M. obesus, M. longisporus, M. pseudokoi, M. bartai, M. pendula, and $M$. bilobus n. sp., with those species from the separate continents grouping together (the exception being $M$. longisporus which aligns with the North American species). It appears that the ancestor to this clade was a parasite of a cyprinid host(s) prior to the separation of North America and Europe/Eurasia. Following geographical isolation and subsequent evolution of cyprinids on the 2 continents, radiation of this myxozoan lineage was complex, involving both host and site switching. We conclude this because these parasites are host specific and occupy as a group a variety of sites within gill and muscle tissues (Molnár \& Baska 1999, Salim \& Desser 2000, Molnár et al. 2002, Dyková et al. 2003, Rácz et al. 2004).

Acknowledgements. This work was supported by a Natural Sciences and Engineering Council of Canada Discovery Grant awarded to D.K.C. The authors thank G. Ridout and staff of the Harkness Fisheries Research Laboratory for help in collecting samples of fish and for providing laboratory space for the research.

\section{LITERATURE CITED}

Cone DK (1994) Annual cycle of Henneguya doori (Myxosporea) parasitizing yellow perch (Perca flavescens). J Parasitol 80:900-904

Cone DK, Wiles M (1985) Trophozoite morphology and development sites of two species of Myxobolus (Myxozoa) parasitizing Catostomus commersoni and Notemigonus crysoleucas in Atlantic Canada. Can J Zool 63:2919-2923

Dyková I, Lom J (1978) Histopathological changes in fish gills infected with myxosporidian parasites of the genus Henneguya. J Fish Biol 12:197-202

Dyková I, Fiala I, Nie P (2003) New data on Myxobolus longisporus (Myxozoa: Myxobolidae), a gill infecting parasite of carp, Cyprinus carpio haematopterus, from Chinese lakes. Folia Parasitol 50:263-268

Easy RH, Johnson SC, Cone DK (2005) Morphological and molecular comparison of Myxobolus procerus (Kudo, 1934) and $M$. intramusculi n. sp. (Myxozoa) parasitizing muscles of the trout-perch Percopsis omiscomaycus. Syst Parasitol 61:115-122

Hillis DM, Dixon MT (1991) Ribosomal DNA: molecular evolution and phylogenetic inference. Q Rev Biol 66:411-453

Kudo RR (1934) Studies on some protozoan parasites of fishes of Illinois. Ill Biol Monogr 13:7-44

Lewis WM, Summerfelt RC (1964) A myxosporidian, Myxobolus notemigoni sp. n., parasite of the golden shiner. J Parasitol 50:386-389

Li L, Desser SS (1985) The protozoan parasites of fish from two lakes in Algonquin Park, Ontario. Can J Zool 63: 1846-1858

Lom J, Dyková I, Horner RW, Hoffman GL, Durham L (1992) Comments on the identity of Myxobolus aureatus. J Aquat Anim Health 4:129-134

Martyn A, Hong H, Ringuette M, Desser SS (2002) Changes in host and parasite-derived cellular and extracellular matrix components in developing cysts of Myxobolus pendula (Myxozoa). J Eukaryot Microbiol 49:175-182

Mavor JW (1916) Studies on the protozoan parasites of the fishes of the Georgian Bay. Trans R Soc Can 10:63-73

Molnár K (1998) Taxonomic problems, seasonality and histopathology of Henneguya creplini (Myxosporea) infection of the pikeperch Stizostedion lucioperca in Lake Balaton. Folia Parasitol 45:261-269

Molnár K (2002) Site preference of fish myxosporeans in the gill. Dis Aquat Org 48:197-207

Molnár K, Baska F (1999) Redescription of Myxobolus hungaricus Jaczo, 1940 (Myxosporea: Myxobolidae), a parasite of bream (Abramis brama L.). Acta Vet Hung 47: 341-349

Molnár K, Eszterbauer E, Székely C, Dán Á, Harrach B (2002) Morphological and molecular biological studies on intramuscular Myxbolus spp. of cyprinid fish. J Fish Dis 25: $543-652$

Presnell JK, Schreibman M (1997) Humason's animal tissue techniques, 5th edn. Johns Hopkins University Press, Baltimore, MD

Price RL, Mellen JW (1980) Myxobolus microcystus n. sp. (Protozoa: Myxosporida) from the gills of Micropterus salmoides (Lacepede, 1802) in southern Illinois. J Parasitol 66:1019-1021

Rácz OZ, Székely C, Molnár K (2004) Intraoligochaete development of Myxobolus intimus (Myxosporea: Myxobolidae), a gill myxosporean of the roach (Rutilus rutilus). Folia Parasitol 51:199-207

Roberts RJ (1989) Fish pathology. Bailliere Tindall, London

Salim KY, Desser SS (2000) Descriptions and phylogenetic systematics of Myxobolus spp. from cyprinids in Algonquin Park, Ontario. J Eukaryot Microbiol 47:309-318

Spall RD (1974) A new myxosporidan in red and golden shiners. J Parasitol 60:169-171

Swofford DL (2001) PAUP*. Phylogenetic analysis using parsimony ( ${ }^{*}$ and other methods), Version 4 . Sinauer Associates, Sunderland, MA

Thompson JD, Gibson TJ, Plewniak F, Jeanmougin F, Higgins DG (1997) The Clustal X windows interface: flexible strategies for multiple sequence alignment aided by quality analysis tools. Nucleic Acids Res 24:4876-4882

Whipps CM, Adlard RD, Bryant MS, Kent ML (2003) Two unusual myxozoans, Kudoa quadricornis n. sp. (Multivalvulida) from the muscle of godspotted trevally (Carangoides fulvoguttatus) and Kudoa permulticapsula n. sp. (Multivalvulida) from the muscle of spanish mackerel (Scomberomorus commersoni) from the Great Barrier Reef, Australia. J Parasitol 89:168-173 